\title{
Contents of Urinary System Stones in North Marmara Region and Their Distribution by Gender
}

\section{Kuzey Marmara Bölgesi’nde Üriner Sistem Taşlarının İçeriği ve Cinsiyete Göre Dağılımı}

\author{
(1) Ekrem Güner, (1) Kamil Gökhan Şeker \\ Bakırköy Dr. Sadi Konuk Training and Research Hospital, Clinic of Urology, i̇stanbul, Turkiye
}

What's known on the subject? and What does the study add?

This article examines the stone contents in the northern Marmara Region and provides up-to-date information.

\section{Abstract}

Objective: We aimed to determine the contents of kidney stones in our country by evaluating the results of the stone analysis of patients who underwent surgery due to ureteral or kidney stones or experienced spontaneous stone expulsion.

Materials and Methods: Data of patients with urolithiasis who underwent surgery due to ureteral or kidney stones or experienced spontaneous stone expulsion in our clinic between 1999 and 2019 were retrospectively analyzed.

Results: Results of 1304 urinary system stone analyses were obtained. 869 (66.6\%) patients were male and 435 (33.4\%) were female. The maleto-female ratio was 1.99:1. The mean age of the patients was $43.2 \pm 15.3$ years. Among 1304 urinary system stones, 734 (56.3\%) had a single component, while 570 (43.7\%) contained more than one substance. The most common stone type was calcium oxalate monohydrate (43\%) and the second most common stone type was the composition of calcium oxalate monohydrate and calcium oxalate dihydrate (21.3\%). The rate of uric acid stone was $6.8 \%$ and the rate of cystine stone was 2.1\%. Any amount of calcium oxalate, uric acid and cystine were observed in $85.3 \%, 12.2 \%$ and $5.4 \%$ of urinary tract stones, respectively.

Conclusion: Urinary system stone disease is approximately two times more frequent in men than in women in Turkiye and the most common stone component is calcium oxalate.

Keywords: Urolithiasis, Calcium oxalate, Uric acid, Cystine

Öz

Amaç: Üreter veya böbrek taşı sebebiyle opere edilen veya spontan taş düşüren hastaların taş analiz sonuçlarını değerlendirerek ülkemizdeki böbrek taşlarının içeriğini belirlemeyi amaçladık.

Gereç ve Yöntem: Kliniğimizde 1999-2019 yılları arasında üreter veya böbrek taşları sebebiyle opere edilen veya spontan taş düşüren ürolitiazis hastalarının verileri retrospektif olarak incelendi.

Bulgular: Toplam 1304 üriner sistem taş analizi sonucu elde edildi. Hastaların 869'u (\%66,6) erkek, 435'i (\%33,4) kadındı. Erkek/kadın oranı 1,99:1 idi. Hastaların yaş ortalaması 43,2 215,3 idi. 1304 üriner sistem taşından 734'ü $(\% 56,3)$ tek bir bileşene sahipken, 570'i $(\% 43,7)$ birden fazla bileşen içermekteydi. En yaygın taş tipi kalsiyum okzalat monohidrat (\%43) taşı ve ikinci en sık taş tipi ise kalsiyum okzalat monohidrat ve kalsiyum okzalat dihidrat $(\% 21,3)$ bileşimiydi. Ürik asit taşı oranı \%6,8 ve sistin taşı oranı \%2,1 idi. Üriner sistem taşlarında herhangi bir miktarda kalsiyum okzalat, ürik asit ve sistin sırasıyla \%85,3, \%12,2 ve \%5,4 oranında gözlendi.

Sonuç: Üriner sistem taş hastalığı Türkiye'de erkeklerde kadınlara göre yaklaşık iki kat daha sık görülmektedir ve en yaygın taş bileşeni kalsiyum oksalattır.

Anahtar Kelimeler: Ürolitiyazis, Kalsiyum okzalat, Ürik asit, Sistin

Correspondence: Ekrem Güner MD, Bakırköy Dr. Sadi Konuk Training and Research Hospital, Clinic of Urology, İstanbul, Turkiye E-mail: ekremguner@yahoo.com ORCID-ID: orcid.org/0000-0002-4770-7535

Received: $30.09 .2019 \quad$ Accepted: 12.11.2019

Cite this article as: Güner E, Şeker KG. Contents of Urinary System Stones in North Marmara Region and Their Distribution by Gender. J Urol Surg 2020;7(1):33-36

๑Copyright 2020 by the Association of Urological Surgery / Journal of Urological Surgery published by Galenos Publishing House. 


\section{Introduction}

The incidence of urinary system stone disease has gradually increased in the United States of America, Europe, and the Far East after World War 2 (1). It has been reported that the prevalence of urinary system stone disease varied between 1\% and 20\% (2). In a study made in Turkiye in 1991, the prevalence of urinary system stone disease was found to be $14.8 \%$ and the prevalence of stones in males was 1.5 times higher than in females (3).

The incidence of urinary system stone disease depends on many factors such as geographical, climatic, hereditary, ethnic and nutritional characteristics. Infectious causes, anatomic anomalies, and drug use also may play a role in stone formation. Urinary system stones may be formed by many different substances. While some stones are formed by a single substance, some others may contain more than one substance. In addition to treatment, determining stone content is important for preventing recurrence (2). Spontaneously passed or surgically removed urinary system stones can be used for analysis. Different methods are used for stone analysis.

Our aim in this study was to present the content of urinary system stones commonly observed in our country by evaluating the stone analysis results of patients who were operated through open, endoscopic or laparoscopic methods or experienced stone expulsion after extracorporeal shock wave lithotripsy (ESWL) or spontaneously. Thus, the contribution can be made to form different health policies to prevent kidney stones, a severe public health problem.

\section{Materials and Methods}

After obtaining local ethics committee approval (20/05/20192019/243), data of urinary system stone patients who underwent open nephrolithotomy, nephropyelolithotomy, percutaneous nephrolithotomy, open or laparoscopic pyelolithotomy and ureterolithotomy, semi-rigid or flexible ureterorenoscopy and ESWL due to kidney or ureteral stone in our clinic or passed stones spontaneously between 1999 and 2019 were examined retrospectively. All female and male patients with data on stone analysis results were included in the study without age restriction. Examined parameters included demographic information and stone analysis results. First stone analyses based on the chronological order were considered for patients who had multiple operations. Patients without data on stone analysis results were excluded from the study.

Stone analyses were made using infrared spectroscopy, X-ray diffraction or polarization microscopy in different laboratories by expert chemists.

\section{Statistical Analysis}

IBM SPSS statistics for Mac version 21 (Chicago, IL, USA) was used for data analysis. While constant variables were given in mean \pm standard deviation, categorical variables were given in numbers and percentages. In the comparison of the two groups, the Mann-Whitney $U$ test was used for numeric data and chisquare tests were used for categorical variables. A $p$ value of less than 0.05 was considered statistically significant.

\section{Results}

Urinary system stone analysis results of a total of 1304 patients were obtained. Eight hundred and sixty-nine patients (66.6\%) were male and 435 (33.4\%) were female. The male-to-female ratio was 1.99:1. The age of the patients varied from 2 to 72 with an average of $43.2 \pm 15.3$ years. While 734 urinary system stones out of 1304 (56.3\%) had a single component, 570 (43.7\%) contained more than one substance. The stones were divided into 16 subgroups based on analysis results (Figure 1). The most common stone type was calcium oxalate monohydrate (43\%) followed by stones composed of calcium oxalate monohydrate and calcium oxalate dihydrate with a rate of $21.3 \%$. The incidence of uric acid stones and cystine stones was 6.8\% and $2.1 \%$, respectively. Different amounts of calcium oxalate were observed in $85.3 \%$, uric acid in $12.2 \%$ and cystine $5.4 \%$ of in urinary system stones. The average age of patients with cystine stone was significantly lower than others $(30.9 \pm 20.8$ years vs $43.9 \pm 14.6$ years; $p<0.01$ ) (Figure 2 ). No relationship could be shown between calcium oxalate, cystine and uric acid stone content and gender $(p=0.741, p=0.515$ and $p=0.419$, respectively).

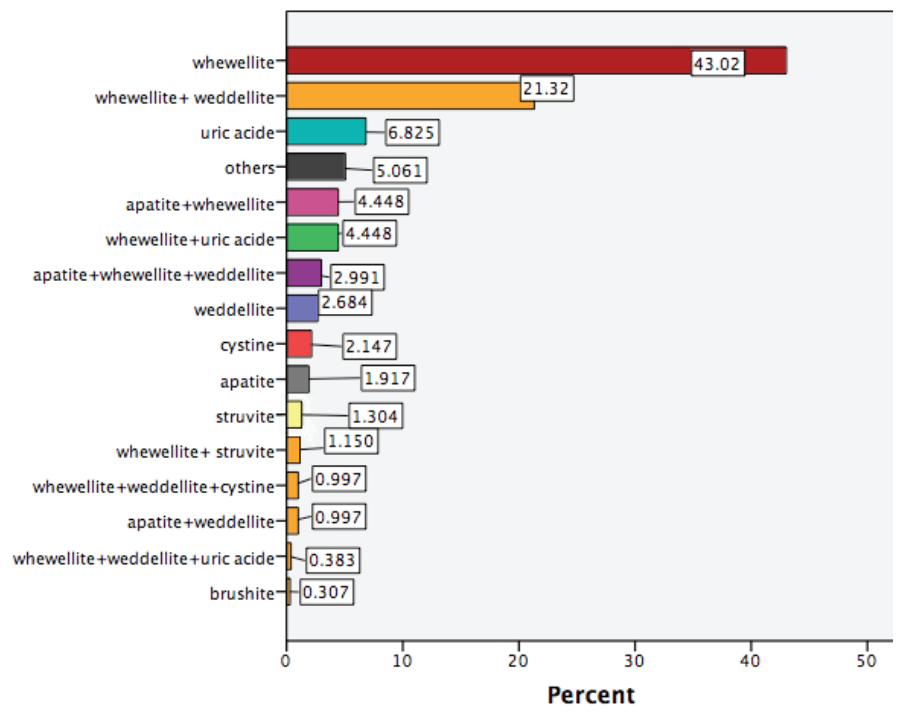

Figure 1. The distribution of stone according to ingredients 


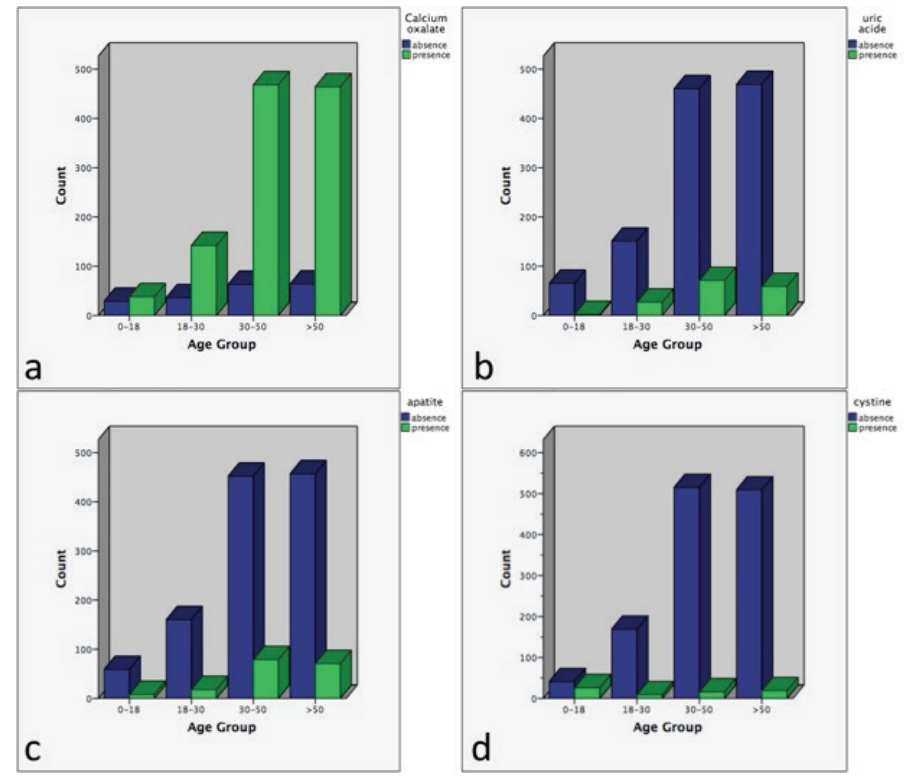

Figure 2. Stone distribution according to age

\section{Discussion}

Urinary system stone disease is a prevalent public health problem around the world although it is more commonly observed in some regions. Its prevalence has been reported to be over 10\% especially in countries with high standards of living, reaching $37 \%$ in some regions with an increasing stone prevalence in the last 20 years (2). 50\% of individuals with urinary system stone disease have the possibility of recurrent stone formation within five years. Thus, in addition to treating the current stone, preventing recurrent stone formation is of vital importance. Thus, the European Association of Urology guidelines recommends stone analysis in all patients who have their first stone (2).

In a study made by Muslumanoglu et al. (4), the prevalence of urinary system stone disease was found to be between $11.1 \%$ and $13.2 \%$. Stone prevalence was reported to increase with age both in males and females and while it is $8 \%$ in individuals younger than 25 years of age, it was $26.6 \%$ in those $45-55$ years of age. Based on the distribution of stone patients in different regions, the prevalence was found to be lowest in the Black Sea region with 9.5\%, while it was highest in the Aegean Region with 12.6\%. Stone patients in Marmara Region constituted 11.4\% of all stone patients in Turkiye. In another study made with 6453 stone patients by Karabacak et al. (5) in our country, calcium oxalate stones were the most commonly detected kidney stones with a rate of $80.4 \%$. These were followed by uric acid stones with a rate of $4.8 \%$, cystine stones with $3.1 \%$ and phosphatecontaining (dahlite, brushite, struvite, whitlockite) stones with $3.3 \%$. The male-to-female ratio was reported to be $2: 1$. Similar to the study by Karabacak et al. (5) calcium oxalate stones were the most common stone content and the male/female ratio was 1.99:1 in our study.

When stone analysis results of individuals having symptomatic kidney stone for the first time were examined in a study made by Singh et al. (6) in the United States, it was found that the content of stones was calcium oxalate in $76 \%$, hydroxyapatite in $18 \%$ and uric acid in $4.8 \%$ of patients. Symptomatic recurrence rate in 10 years was detected to be nearly $50 \%$ in brushite, struvite and uric acid stones and 30\% in calcium oxalate and hydroxyapatite stones. These results could not be provided as we do not have data on recurrence in our current study.

In a study made by Ye et al. (7) it was shown that among 49.317 stone samples, 16.361 were formed (33.2\%) by a single component, $20.370(41.3 \%)$ by two components and 11.314 $(22.9 \%)$ by three components. While the most common stone content was calcium oxalate with a rate of $65.9 \%$, carbapatite followed this with $15.6 \%$, urate with $12.4 \%$, struvite with $2.7 \%$ and brushite with $1.7 \%$. In our study, $56.3 \%$ of the stones contained a single substance.

In another study made by Safarinejad (8), it was shown that urinary system stone disease prevalence increased with age and while it was $0.9 \%$ between the ages of 15 and 29, it increased to $8.2 \%$ between the ages 60 and $69(p=0.001)$. The average age of the patients was $43.2 \pm 15.3$ years in our study.

In a study made by Tyson et al. (9) in Ireland, it was found that 94.5\% of urinary system stones contained different amounts of calcium. The rate of stones containing calcium oxalate and phosphate mixture was reported to be $73.1 \%$ and pure calcium oxalate stone rate was reported to be $2.5 \%$. In total, any amount of uric acid was found in $9.6 \%$ of stones and struvite in 13.7\%. Pure cystine was detected in 1.1\% of stones, as expected. Any amount of uric acid was found in $12.2 \%$ of stones in our current study, this rate was $5.4 \%$ for cystine. High cystine stone rate can be explained by genetic background.

In a study made by Luo et al. (10) in China, it was reported that $69.4 \%$ of 732 patients who had stone analysis were male and $30.6 \%$ were female. The male-to-female ratio was $2.27: 1$. In this study, it was observed that $63.8 \%$ of the stones contained a single component. The most common stone type was ammonium urate with a prevalence rate of $35.6 \%$ in males and $33.4 \%$ in females. Calcium oxalate monohydrate stones were detected in $30.9 \%$ of males and $31.2 \%$ of females. When evaluated in age groups, stone formation peaked between 1 and 3 years of age for individuals under 18 years of age and between 19 and 40 for those over 18 years of age. We did not find any relationship between stone type and gender in our study. The average age of patients who had only cystine as a component was significantly lower than those without cystine. 


\section{Study Limitations}

Our study has some limitations. First of all, this is a retrospective study. Lack of knowledge of the ethnical backgrounds, body mass index and urinary system stone recurrence conditions of the patients precluded more detailed analysis. Also, the fact that the study covered patients in a period of 20 years, which is a long period, may have affected the stone analysis methods and results. Stone analyses not made in a single center may have caused the differences.

\section{Conclusion}

Urinary system stones are observed nearly two times more frequently in males than in females in Turkiye. The most common stone component is calcium oxalate.

\section{Ethics}

Ethics Committee Approval: Obtaining local ethics committee approval (20/05/2019-2019/243).

Informed Consent: This study does not include any patient.

Peer-review: Internally peer-reviewed.

\section{Authorship Contributions}

Concept: E.G., K.G.Ş., Design: E.G., K.G.Ş., Supervision: E.G., Data Collection or Processing: E.G., K.G.Ş., Analysis or Interpretation: E.G., K.G.Ş., Literature Search: E.G., K.G.Ş., Writing: E.G., K.G.Ş.,

Conflict of Interest: No conflict of interest was declared by the authors.

Financial Disclosure: The authors declare that they have no relevant financial.

\section{References}

1. Yoshida O, Terai A, Ohkawa T, Okada Y. National trend of the incidence of urolithiasis in Japan from 1965 to 1995. Kidney Int 1999;56:1899-1904.

2. Türk C, Neisius A, Petrik A, Seitz C, Skolarikos A, Thomas K. EAU Guidelines on Urolithiasis 2018.

3. Akinci M, Esen T, Tellaloğlu S. Urinary stone disease in Turkey: an updated epidemiological study. Eur Urol 1991;20:200-203.

4. Muslumanoglu AY, Binbay M, Yuruk E, Akman T, Tepeler A, Esen T, Tefekli AH. Updated epidemiologic study of urolithiasis in Turkey. I: Changing characteristics of urolithiasis. Urol Res 2011;39:309-314.

5. Karabacak OR, Dilli A, Saltaş H, Yalçınkaya F, Yörükoğlu A, Sertçelik MN. Stone compositions in Turkey: an analysis according to gender and region. Urology 2013;82:532-537.

6. Singh P, Enders FT, Vaughan LE, Bergstralh EJ, Knoedler JJ, Krambeck AE, Lieske JC, Rule AD. Stone Composition Among First-Time Symptomatic Kidney Stone Formers in the Community. Mayo Clin Proc 2015;90:13561365.

7. Ye Z, Zeng G, Huan Y, Li J, Tang $K$, Wang G, Wang S, Yu Y, Wang Y, Zhang $T$, Long $Y$, Li W, Wang C, Wang W, Gao S, Shan Y, Huang $X$, Bai Z, Lin $X$, Cheng Y, Wang Q, Xu Z, Xie L, Yuan J, Ren S, Fan Y, Pan T, Wang J, Li X, Chen X, Gu X, Sun Z, Xiao K, Jia J, Zhang Q, Wang G, Sun T, Li X, Xu C, Xu C, Shi G, He J, Song L, Sun G, Wang D, Liu Y, Wang C, Han Y, Liang P, Wang Z, He W, Chen Z, Xing J, Xu H. The Status and Characteristics of Urinary Stone Composition in China. BJU Int 2019.

8. Safarinejad MR. Adult urolithiasis in a population-based study in Iran: prevalence, incidence, and associated risk factors. Urol Res 2007;35:73-82.

9. Tyson M, Grimes N, McAuley L, Hennessy D, Pahuja A, Young M. Renal and Ureteric Stone Composition: A five year retrospective study for Northern Ireland. Ulster Med J 2019;88:21-24.

10. Luo J, Tuerxun A, Shataer A, Batuer A, Jiang C, Zhou Y, Li Z, Chen D, Liu Y Kidney Stone Composition in Third-World Areas: What Kashgar Tells Us? J Endourol 2018:32:465-470 